\title{
Feeding a brown midrib corn silage-based diet to growing beef steers improves growth performance and economic returns
}

\author{
C. S. Saunders ${ }^{1}$, S. Y. Yang ${ }^{1,3}$, J.-S. Eun ${ }^{1}$, D. M. Feuz ${ }^{2}$, and D. R. ZoBell ${ }^{1}$ \\ ${ }^{1}$ Department of Animal, Dairy, and Veterinary Sciences, Utah State University, Logan, UT 84322, USA; and \\ ${ }^{2}$ Department of Applied Economics, Utah State University, Logan, UT 84322, USA. \\ Received 16 March 2015, accepted 6 August 2015. Published on the web 24 August 2015.
}

\begin{abstract}
Saunders, C. S., Yang, S. Y., Eun, J.-S., Feuz, D. M. and ZoBell, D. R. 2015. Feeding a brown midrib corn silage-based diet to growing beef steers improves growth performance and economic returns. Can. J. Anim. Sci. 95: 625-631. A feedlot experiment was performed to determine growth performance, ruminal fermentation characteristics, and economic returns for growing beef steers when fed a brown midrib corn silage-based total mixed ration (BMRT) compared with a conventional corn silagebased total mixed ration (CCST). Twenty-four Angus crossbred steers (initial body weight $=258 \pm 23.2 \mathrm{~kg}$ ) in individual pens were used in a completely randomized design $(n=12)$. Intake of dry matter was not different between the treatments. Steers fed the BMRT tended to have greater average daily gain (1.54 vs. $\left.1.42 \mathrm{~kg} \mathrm{~d}^{-1} ; P=0.09\right)$ and gain-to-feed ratio (0.165 vs. 0.146; $P=0.07)$ compared with those fed the CCST. Feeding the BMRT increased total volatile fatty acid (VFA) concentration $(P=0.01)$ compared with the CCST, while it decreased molar proportion of acetate $(P<0.01)$, and increased propionate proportion $(P=0.01)$, resulting in decreased acetate-to-propionate ratio compared with the CCST $(P<0.01)$. Steers fed the BMRT increased feed margin $(P=0.05)$ and net return $(P=0.02)$ compared with those fed the CCST throughout the trial. Overall results of this study indicate that feeding the BMRT to growing beef steers enhanced ruminal fermentation and beneficially shifted VFA profiles, which contributed to improved growth and economic performance of steers.
\end{abstract}

Key words: Brown midrib corn silage, economic performance, growing beef steers, growth performance, ruminal fermentation

\begin{abstract}
Saunders, C. S., Yang, S. Y., Eun, J.-S., Feuz, D. M. et ZoBell, D. R. 2015. Alimenter les bœufs de boucherie en croissance d'une diète à base d'ensilage de maïs à nervure brune améliore la performance de croissance et les rendements économiques. Can. J. Anim. Sci. 95: 625-631. Une expérience en parc d'engraissement a été effectuée pour déterminer la performance de croissance, les caractéristiques de fermentation ruminale et les rendements économiques chez les bæufs de boucherie en croissance lorsque nourris une ration totale mixte à base de maïs à nervure brune (BMRT - « brown midrib corn silage-based total mixed ration ») par rapport à ceux nourris d'une ration totale mixte traditionnelle à base d'ensilage de maïs (CCST « conventional corn silage-based total mixed ration »). Vingt-quatre bouvillons Angus croisés (poids corporel initial $=258 \pm$ $23,2 \mathrm{~kg})$ dans des enclos individuels ont été utilisés dans un design complètement aléatoire $(n=12)$. L'ingestion des matières sèches (DM - «dry matter ») ne différait pas entre les traitements. Les bouvillons alimentés à la diète BMRT tendaient vers de plus grands gains moyens quotidiens (ADG - «average daily gain »; 1,54 c. 1,42 $\mathrm{kg}_{\text {jour }}^{-1} ; P=0,09$ ) et indices de consommation $(0,165$ c. 0,$146 ; P=0,07)$ par rapport à ceux ayant reçu la diète CCST. L'alimentation à la diète BMRT a augmenté la concentration d'acides gras volatils totaux (VFA - « volatile fatty acid») $(P=0,01)$ par rapport à la diète CCST, tandis qu'elle a diminué la proportion molaire d'acétate $(P<0,01)$ et a augmenté la proportion de propionate $(P=0,01)$, ayant comme résultat une diminution du ratio acétate à propionate par rapport à la diète CCST $(P<0,01)$. Les bouvillons nourris à la diète BMRT ont vu une augmentation de leur marge d'aliments $(P=0,05)$ et de leurs retours nets $(P=0,02)$ par rapport à ceux nourris à la diète CCST pendant toute la période d'étude. Les résultats généraux de cette étude indiquent que donner une diète BMRT aux bovins de boucherie en croissance améliore la fermentation ruminale et a un effet positif sur les profils de VFA, ce qui contribue à une meilleure performance de croissance et économique des bouvillons.
\end{abstract}

Mots clés: Ensilage de maïs à nervure brune, performance économique, bœufs de boucherie en croissance, performance de croissance, fermentation ruminale

Approved as Journal Paper No. 8816 of the Utah Agricultural Experiment Station, Utah State University, Logan, UT, USA.

${ }^{3}$ Corresponding author (e-mail: sy.yang@usu.edu).
Abbreviations: ADF, acid detergent fiber; ADG, average daily gain; BMR, brown midrib corn silage; BMRT, brown midrib corn silage-based TMR; BW, body weight; CCS, conventional corn silage; CCST, conventional corn silage-based TMR; CP, crude protein; cwt, hundredweight; DM, dry matter; DMI, dry matter intake; G:F, gain-to-feed ratio; NDF, neutral detergent fiber; TMR, total mixed ration; VFA, volatile fatty acids 
The need for improving feed efficiency in ruminant production to address increasing costs of production and environmental challenges necessitates optimization of nutrient utilization in ruminant diets. The application of this concept in forage-based feeding programs in ruminants can be achieved through conventional forage breeding as well as effective forage feeding programs. Chemical and genetic approaches have been employed to improve forage fiber digestibility by decreasing the extent of lignin concentration or lignin cross-linking with cell wall carbohydrates. Brown midrib (BMR) forage genotypes usually contain less lignin and may have altered lignin chemical composition (Bucholtz et al. 1980; Cherney et al. 1991; Vogel and Jung 2001). Brown midrib corn is generally viewed as being lower yielding than non-BMR corn, but feeding BMR silage has increased milk production for dairy cows due to its lower lignin concentration and associated increase in ruminal digestibility and fermentability (Gencoglu et al. 2008; Sattler et al. 2010). Digestibility of forage fiber affects growth performance in rapidly growing beef steers. In addition, providing adequate dietary concentrations of digestible fiber in cattle rations is essential for animal health, as it is required to support an appropriate rumen function (Campbell et al. 1992; González et al. 2012).

Typically, growing beef steers are fed forage-based diets, but lack of energy from forages and distention from rumen fill may limit dry matter intake (DMI) and reduce performance for high-producing dairy cows and rapidly growing beef steers (Holt et al. 2010, 2013a, b). Therefore, great emphasis has been placed on dietary factors affecting DMI of cattle. The rumen-filling effect of diets is influenced most by concentration, digestibility, and fragility of forage neutral detergent fiber (NDF) (Allen and Bradford 2011). Feeding forages with enhanced digestibility of NDF improved DMI and milk yield in dairy cows (Oba and Allen 1999). Corn silage with the BMR mutation has been well documented to have greater fiber digestibility than conventional corn silage (CCS) and will likely increase DMI and milk yield compared with cows fed CCS (Eastridge 1999; Gencoglu et al. 2008). Therefore, energy sources high in digestible fiber, such as BMR, may allow for increased energy intake without disruption of fiber digestion and improve ruminal fermentation, which can enhance growth performance of growing beef steers.

A series of dairy cow lactation experiments using BMR have indicated increased milk yield and feed and $\mathrm{N}$ efficiencies by cows fed BMR at 35\% dry matter (DM) with minor effects on ruminal fermentation profiles (Holt et al. 2013a, b). In addition, observations by producers and beef nutritionists indicate that beef producers in the Intermountain West, USA (i.e., Utah, Idaho, Wyoming, Montana, and parts of Arizona and Nevada) have increased their use of corn silage as a forage source in beef rations due to the high price of feed, especially corn grain, and the high energy content of corn silage. The previous results and the current interest led us to determine if increased ruminal fermentability with feeding BMR at a greater dietary concentration (49\% DM) would affect growth performance of growing beef steers. The objectives of this study were to investigate the influence of feeding a BMR-based diet to growing beef steers on the following: (1) growth and feed intake, (2) ruminal fermentation profiles, and (3) economic returns by comparison with those fed CCS-based diet.

\section{MATERIALS AND METHODS}

The beef steers used in this study were cared for according to the Live Animal Use in Research Guidelines of the Institutional Animal Care and Use Committee at Utah State University, Logan, UT.

\section{Animals, Experimental Design, and Diets}

The experiment was conducted at the Utah State University Beef Research Unit (Wellsville, UT), from October 2012 to January 2013. Twenty-four Angus crossbred steers $(258 \pm 23.2 \mathrm{~kg})$ were randomly assigned to one of two dietary treatments: CCS-based total mixed ration (TMR; CCST) and BMR-based TMR (BMRT). The two treatments were assigned to 12 steers each housed in individual pens in a completely randomized design, resulting in 12 replications per treatment. The steers were adapted to experimental setup in their pens for $2 \mathrm{wk}$ and were fed the CCST during the adaptation period. The CCST contained $48.1 \%$ CCS, $15.4 \%$ alfalfa hay, $31.7 \%$ dry-rolled barley grain, and $5.3 \%$ feedlot supplement, whereas the BMRT consisted of $49.0 \%$ BMR, $16.0 \%$ alfalfa hay, $30.0 \%$ barley grain, and $5.0 \%$ feedlot supplement on a dry matter (DM) basis (Table 1). The two dietary treatments had similar concentrations of crude protein $(\mathrm{CP}), \mathrm{NDF}$, acid detergent fiber (ADF), and starch.

All steers were fed once per day, and the amounts of feed offered and refused were recorded each afternoon. These were used to determine the amount of feed that needed to be delivered to each pen the following day. The steers were fed a TMR for ad libitum intake with at least $10 \%$ of daily feed refusal and had ad libitum access to fresh water. Steers were weighed every $28 \mathrm{~d}$, with weights obtained on 2 consecutive days at the beginning and end of the treatment period. The respective corn silages used in the diets were prepared from two corn silage hybrids, conventional (Pioneer 9714; Pioneer Hi-breed International, Inc., Johnston, IA) and BMR (Mycogen Seeds, Indianapolis, IN) that were planted in spring 2011. Corn silages were harvested at approximately $30 \%$ whole plant DM using a pull-type harvester (Model FP230, New Holland, PA) equipped with a mechanical processor, and treated with a silage inoculant (Silage $\mathrm{PT}^{\circledR}$, Nurturite, Twin Falls, ID) at a rate of $112 \mathrm{~g} \mathrm{t}^{-1}$ of fresh forage to enhance Lactobacillus fermentation. Silage hybrids were placed in bag silos ( $\mathrm{Ag} / \mathrm{Bag}$ International Ltd., Warrenton, OR) and ensiled for $120 \mathrm{~d}$. Alfalfa was preserved as sun-cured hay and processed for approximately $15 \mathrm{~min}$ in a TMR wagon (model 455, Roto-Mix, Dodge City, KS). The CCS 


\begin{tabular}{lcc}
\hline $\begin{array}{l}\text { Table 1. Ingredients and chemical composition of growing beef steer diets } \\
(\boldsymbol{n}=\mathbf{3})\end{array}$ & \multicolumn{2}{c}{ Diet $^{\mathbf{z}}$} \\
\cline { 2 - 3 } & CCST & BMRT \\
Item & & \\
\hline Ingredient (\% DM) & 48.1 & - \\
Conventional corn silage & - & 49.0 \\
Brown midrib corn silage & 15.4 & 16.0 \\
Alfalfa hay, chopped & 31.7 & 30.0 \\
Barley grain, dry rolled & 5.3 & 5.0 \\
Feedlot supplement & & \\
Chemical composition (\% DM) & $49.7 \pm 0.67$ & $50.0 \pm 0.50$ \\
Dry matter (\%) & $91.5 \pm 1.82$ & $91.8 \pm 1.09$ \\
Organic matter & $10.2 \pm 0.25$ & $10.6 \pm 0.31$ \\
Crude protein & $34.8 \pm 2.92$ & $32.7 \pm 2.09$ \\
Neutral detergent fiber & $17.8 \pm 2.09$ & $17.1 \pm 1.03$ \\
Acid detergent fiber & $28.0 \pm 2.60$ & $27.7 \pm 2.30$ \\
Starch & $2.74 \pm 0.31$ & $2.50 \pm 0.29$ \\
Ether extract & $0.81 \pm 0.05$ & $0.79 \pm 0.16$ \\
Ca & $0.30 \pm 0.03$ & $0.27 \pm 0.04$ \\
P & &
\end{tabular}

${ }^{\mathrm{z} C C S T}$, conventional corn silage-based TMR; BMRT, brown midrib corn silage-based TMR.

${ }^{\mathbf{y}}$ Composition: $5.0 \% \mathrm{NaCl}, 0.24 \% \mathrm{Mg}, 0.76 \% \mathrm{~K}, 200 \mathrm{ppm} \mathrm{Cu}, 400 \mathrm{ppm} \mathrm{Mn}$, 650 ppm Zn, 2 ppm Se, 22 ppm I, 9 ppm Co, 121,000 IU kg ${ }^{-1}$ vitamin A, $37400 \mathrm{IU} \mathrm{kg}^{-1}$ vitamin D, $55 \mathrm{IU} \mathrm{kg}^{-1}$ vitamin E, and $360 \mathrm{ppm}$ Rumensin ${ }^{\circledR}$ (Elanco Animal Health, Indianapolis, IN).

contained (DM basis) $8.40 \pm 0.419 \% \mathrm{CP}, 38.1 \pm 4.92 \%$ $\mathrm{NDF}, 17.8 \pm 3.09 \%$ ADF, and $28.0 \pm 2.60 \%$ starch, whereas BMR had $8.30 \pm 0.369 \%$ CP, $33.9 \pm 2.09 \%$ $\mathrm{NDF}, 17.1 \pm 1.03 \% \mathrm{ADF}$, and $27.7 \pm 2.30 \%$ starch.

\section{Sampling, Data Collection, and Chemical Analyses}

Samples of the TMR fed and orts for individual steers were collected weekly, dried at $60^{\circ} \mathrm{C}$ for $48 \mathrm{~h}$, ground to pass a $1-\mathrm{mm}$ screen (standard model 4; Arthur $\mathrm{H}$. Thomas Co., Swedesboro, NJ), and stored for subsequent analyses. Contents of DM of the samples were used to calculate DMI. Analytical DM concentration of samples was determined by oven drying at $135^{\circ} \mathrm{C}$ for $2 \mathrm{~h}$; organic matter was determined by ashing, and $\mathrm{N}$ concentration was determined using an elemental analyzer (Flash 2000 N/Protein Analyzer, Thermo Scientific, Cambridge, UK) (Association of Official Analytical Chemists 2000). The NDF and ADF concentrations were sequentially determined using an ANKOM $^{200 / 220}$ Fiber Analyzer (ANKOM Technology, Macedon, NY) according to the methodology supplied by the company. Sodium sulfite was used in the procedure for NDF determination and pre-treatment with heat-stable amylase (Type XI-A from Bacillus subtilis; Sigma-Aldrich Corporation, St. Louis, MO). Starch concentration of feed was determined by a two-step enzymatic method (Rode et al. 1999) with a microtiter plate reader (Dynatech Laboratories, Chantilly, VA) to read glucose release colorimetrically at $490 \mathrm{~nm}$. Calcium and phosphorus of the feed samples were analyzed using methods described by Isaac and Johnson (1985).

\section{Ruminal Fermentation Profiles}

Ruminal fluid samples were obtained using an oral stomach tube (Geishauser 1993) $3 \mathrm{~h}$ after morning feeding during weeks 4,8 , and 12 . The $\mathrm{pH}$ of the ruminal fluid was measured within 5 min of collecting the samples using a portable $\mathrm{pH}$ meter (Oakton pH6; Oakton Instruments, Vernon Hills, IL). Five milliters of ruminal fluid were frozen and stored at $-40^{\circ} \mathrm{C}$ for volatile fatty acid (VFA) analysis. Ruminal VFA were separated and quantified using a GLC (model 6890 series II; Hewlett-Packard Co., Avondale, PA) with a capillary column $(30 \mathrm{~m} \times 0.32 \mathrm{~mm}$ i.d., 1- $\mu \mathrm{m}$ phase thickness, Zebron ZB-FAAP; Penomenet Inc., Torrance, $\mathrm{CA}$ ) and flame-ionized detection. The oven temperature was held at $170^{\circ} \mathrm{C}$ for $4 \mathrm{~min}$, increased to $185^{\circ} \mathrm{C}$ at a rate of $5^{\circ} \mathrm{C} \mathrm{min}^{-1}$, then increased by $3^{\circ} \mathrm{C}$ $\min ^{-1}$ to $220^{\circ} \mathrm{C}$, and held at this temperature for $1 \mathrm{~min}$. The injector and the detector temperatures were 225 and $250^{\circ} \mathrm{C}$, respectively, and the carrier gas was helium (Eun and Beauchemin 2007).

\section{Economic Analysis}

For the economic analysis, all feedstuff prices were based on Utah Agricultural Statistics Service (2014). All feedstuff prices were calculated as a dollars per kilogram DM. Beginning and ending feeder cattle prices were based on current prices in Utah provided by USDA-Agricultural Marketing Service (2014) for 226.80$272.16 \mathrm{~kg}$ [\$209.00 per hundredweight (cwt)] and 362.87$408.23 \mathrm{~kg}\left(\$ 187.97 \mathrm{cwt}^{-1}\right)$ steers, respectively. Yardage was included at $\$ 0.28 \mathrm{~d}^{-1}$ steer $^{-1}$ to account for feeding and checking animals and watering daily. Health and processing (vaccination and implant administration) fee was charged over the feeding period at $\$ 13.00$ steer $^{-1}$. Interest rate at $5 \%$ was applied based on initial steer cost divided by $365 \mathrm{~d}$. Feed cost per kilogram of body weight (BW) gain was calculated by total feed cost divided by average daily gain $(\mathrm{ADG}) \times$ days on feed. Total cost per kilogram of BW gain was calculated: (total feed cost + total non-feed cost $) \div($ ADG $\times$ days on feed $)$. Calculating the total non-feed cost was the sum of yardage, health and processing fee, death loss (which was assumed to be $1 \%$ ), and interest. Total feed cost was calculated as the sum of each feedstuff based on average DMI of steers for the total feeding period. The estimated CCS and BMR prices were $\$ 57.3 \mathrm{t}^{-1}$ and $\$ 62.9 \mathrm{t}^{-1}$, respectively, based on seed prices $\left(\$ 7.5 \mathrm{~kg}^{-1} \mathrm{CCS}\right.$ and $\$ 11.9 \mathrm{~kg}^{-1}$ BMR). Feeding margin was calculated by the difference of the beginning and the ending value of steers. The beginning value was calculated by multiplying the beginning $\mathrm{BW}$ and the beginning price of steers $\left(\$ \mathrm{cwt}^{-1}\right)$. The ending value was calculated by multiplying the ending BW and the ending price of steers $\left(\$ \mathrm{cwt}^{-1}\right)$. The net return $\left(\$\right.$ steer $\left.^{-1}\right)$ was calculated by the difference between feed margin, total feed cost, and total non-feed cost. 


\section{Statistical Analysis}

All data in this study were analyzed using the MIXED procedure of SAS software (SAS Institute Inc. 2011). Animal was an experimental unit with monthly data collection periods as repeated measures of treatments. Initial BW measured at the beginning of the trial were used as covariates for the final BW and change of BW analyses. Data were analyzed using the following model:

$$
Y_{\mathrm{ijk}}=\mu+T_{\mathrm{i}}+P_{\mathrm{j}}(T)_{\mathrm{i}}+M_{\mathrm{k}}+T M_{\mathrm{ik}}+\varepsilon_{\mathrm{ijk}}
$$

where, $\mu$ is the overall mean, $T_{\mathrm{i}}$ is the fixed effect of dietary treatment $i, P_{\mathrm{j}}(T)_{\mathrm{i}}$ is the random effect of animal $j$ within dietary treatment $i, M_{\mathrm{k}}$ is the effect of sampling month $k$, $T M_{\mathrm{ik}}$ is the interaction between dietary treatment $i$ and sampling month $k$, and $\varepsilon_{\mathrm{ijk}}$ is the residual error. Because interactions were lacking in all cases, data were reanalyzed using a model that included treatment as a fixed effect and the random effect of animal, with months as repeated measures of the treatments. Simple, autoregressive one, and compound symmetry covariance structures were used in the analysis depending on low values for the Akaike's information criteria and Schwartz's Bayesian criterion. Economic traits were analyzed using a model that included treatment as a fixed effect and the random effect of animal. Significant effects of the treatment were declared if $P \leq 0.05$, and trends were accepted if $0.05<P \leq 0.10$.

\section{RESULTS AND DISCUSSION}

\section{Growth Performance and DMI}

Steers fed the CCST and the BMRT had similar initial and final BW (Table 2). Intake of DM was similar between the treatments, but a tendency for increased ADG (1.54 vs. $\left.1.42 \mathrm{~kg} \mathrm{~d}^{-1} ; P=0.09\right)$ and gain-to-feed ratio (G:F; 0.165 vs. $0.146 ; P=0.07$ ) were observed for steers fed the BMRT compared with those fed the CCST. Contrary to our results, Keith et al. (1981) observed greater DMI (6.18 and $\left.5.71 \mathrm{~kg} \mathrm{~d}^{-1}\right)$ as well as ADG (1.03 and $0.90 \mathrm{~kg} \mathrm{~d}^{-1}$ ) with steers fed BMR compared with those fed the CCS ad libitum without supplemental corn grain. However, the authors observed when the corn grain was fed ( 1 and $2 \%$ of $\mathrm{BW}$ ) with corn silages

\begin{tabular}{|c|c|c|c|c|}
\hline \multirow[b]{2}{*}{ Item } & \multicolumn{2}{|c|}{ Treatment $^{\mathbf{z}}$} & \multirow[b]{2}{*}{ SEM } & \multirow[b]{2}{*}{$P$} \\
\hline & CCST & BMRT & & \\
\hline \multicolumn{5}{|l|}{ Body weight } \\
\hline Initial (kg) & 254.9 & 251.2 & 6.42 & 0.69 \\
\hline Final $(\mathrm{kg})$ & 371.1 & 381.0 & 6.21 & 0.13 \\
\hline Average daily gain DG $\left(\mathrm{kg} \mathrm{d}^{-1}\right)$ & 1.42 & 1.54 & 0.052 & 0.09 \\
\hline Dry matter intake $\left(\mathrm{kg} \mathrm{d}^{-1}\right)$ & 9.72 & 9.35 & 0.296 & 0.38 \\
\hline Gain-to-feed ratio & 0.146 & 0.165 & 0.0069 & 0.07 \\
\hline
\end{tabular}

${ }^{\mathrm{z} C C S T}$, conventional corn silage-based TMR; BMRT, brown midrib corn silage-based TMR. ad libitum, silage intake was decreased (including no difference between BMR and CCS), and fiber digestion was reduced, possibly because of the large amount of readily available carbohydrates in the diet (Keith et al. 1981). Additionally, the authors indicated that rumen microorganisms utilized the more readily available energy from the starch before utilizing the energy of the fiber components of the plant cell wall (Keith et al. 1981). Thus, differences in fiber digestion due to the $b m 3$ gene may have been masked or eliminated by the addition of corn grain to the diet of feedlot cattle (Keith et al. 1981). Tjardes et al. (2000) also observed an increase in DMI $\left(0.43 \mathrm{~kg} \mathrm{~d}^{-1}\right)$ when feeding an $86.3 \%$ BMR diet, but G:F decreased (0.135 vs. 0.145) with no effect on ADG (1.02 vs. $1.01 \mathrm{~kg} \mathrm{~d}^{-1}$ ) compared with when steers were fed CCS. Similarly, Holt et al. (2013a) reported increased DMI and milk yield by dairy cows fed a BMR-based diet compared with a CCS-based diet. Retention of digesta in the rumen functions to supply a more consistent flow of nutrients to the small intestine, but physical fill of the gastrointestinal tract can limit feed intake when highforage diets are fed (Holt et al. 2013a). Oba and Allen (1999) stated that ruminal fill was more limiting to intake for higher-yielding cows and thus increasing NDF digestibility of forage by feeding the BMRT might increase DMI to a greater extent in rapidly growing beef steers. Thus, we expected increased DMI for steers offered the BMRT compared with those fed the CCST, and the absence of an effect of feeding the BMRT on DMI could be attributed to an increased proportion of propionate for steers fed the BMRT compared with those fed the CCST, which will be discussed in more detail later in this paper in the ruminal fermentation profiles. Propionate has been reported to induce hypophagia (Allen 2000), so decreasing propionate production and absorption will likely increase meal size and possibly feed intake (Allen et al. 2009). Energy density also influences feed intake (Mertens 1987; Fisher 2002; Krehbiel et al. 2006). Krehbiel et al. (2006) indicated that DMI decreased across dietary metabolizable energy (ME) values ranging from 2.66 to $3.29 \mathrm{Mcal} \mathrm{kg}^{-1}$ of DM [calculated using values from the National Research Council (NRC) (1996)] in finishing diets. The ME value of the CCST was $2.70 \mathrm{Mcal} \mathrm{kg}{ }^{-1}$ of DM [(calculated using values from NRC (1996) and barley grain processing value reported by Owens et al. (1997)]. The estimated ME value of the BMRT was $2.80 \mathrm{Mcal} \mathrm{kg}^{-1}$ of DM, which was calculated with an assumption of $10 \%$ increased digestibility of BMR compared with CCS. The absence of an effect feeding the BMRT on DMI could be attributed to an increased proportion of propionate and energy density and efficiency in medium-concentrate diets for steers fed the BMRT rather than the CCST. Increases in ADG and G:F but a similar DMI due to feeding the BMRT observed in the current study imply improved nutrient utilization due to feeding BMR to support better growth of growing steers. Chamberlain et al. (1971) observed an increase in ADG (0.83 vs. $\left.0.71 \mathrm{~kg} \mathrm{~d}^{-1}\right)$ 
and G:F ( 0.160 vs. 0.134$)$ when beef heifers were fed latemilk stage corn silage compared with mealy-endosperm stage corn silage with similar DMI (5.2 vs. $5.3 \mathrm{~kg} \mathrm{~d}^{-1}$ ). Similarly, Weller and Phipps (1986) reported that dairy calves fed BMR (bm3 silage) increased ADG compared with those fed CCS (0.92 vs. $\left.0.83 \mathrm{~kg} \mathrm{~d}^{-1}\right)$ with a similar DMI. They indicated that although the DMI of the CCS and BMR by calves was similar, the greater digestibility of the BMR led to increased ADG and G:F (Weller and Phipps 1986). In studies by Chamberlain et al. (1971) and Weller and Phipps (1986), improved nutrient utilization of corn silage led to improved ADG as well as G:F.

\section{Ruminal Fermentation Characteristics}

Feeding the BMRT decreased ruminal $\mathrm{pH}$ compared with the CCST (6.42 vs. 6.67; Table 3). Calsamiglia et al. (2008) reported that the effect of ruminal $\mathrm{pH}$ on NDF digestibility was relatively small when ruminal $\mathrm{pH}$ exceeded 6.0, but digestibility of NDF decreased sharply when $\mathrm{pH}$ was below this threshold. Therefore, in our study, feeding the BMRT would not interfere with ruminal fermentation, as average ruminal $\mathrm{pH}$ for cattle fed BMRT was 6.42. Total VFA concentration increased $(P=0.01)$ due to feeding the BMRT compared with the CCST (89.7 vs. $80.8 \mathrm{mM}$ ). Some studies reported a decrease in ruminal $\mathrm{pH}$ when BMR was fed (Oba and Allen 2000; Taylor and Allen 2005; Gehman et al. 2008). This may have been caused by the increased supply of fermentable substrate in the rumen due to enhanced NDF digestibility of BMR (Weiss and Wyatt 2006).

Feeding the BMRT decreased $(P<0.01)$ the molar proportion of acetate, but increased $(P=0.01)$ propionate proportion, resulting in decreased $(P<0.01)$ acetateto-propionate ratio compared with the CCST (2.75 vs. 3.39; Table 3). In addition, feeding the BMRT increased the molar proportion of butyrate compared with feeding CCST. In the current study, feeding the BMRT increased total VFA concentration, and favorably shifted ruminal fermentation by increasing propionate proportion but

Table 3. Ruminal fermentation profiles of growing beef steers fed different corn silage hybrids

\begin{tabular}{|c|c|c|c|c|}
\hline \multirow[b]{2}{*}{ Item } & \multicolumn{2}{|c|}{ Treatment $^{\mathbf{z}}$} & \multirow[b]{2}{*}{ SEM } & \multirow[b]{2}{*}{$P$} \\
\hline & CCST & BMRT & & \\
\hline Ruminal pH & 6.67 & 6.42 & 0.034 & $<0.01$ \\
\hline Total VFA (mM) & 80.8 & 89.7 & 2.17 & 0.01 \\
\hline \multicolumn{5}{|l|}{ Individual $\mathrm{VFA}^{\mathbf{y}}$} \\
\hline Acetate (A) & 64.9 & 60.5 & 0.689 & $<0.01$ \\
\hline Propionate (P) & 18.7 & 21.8 & 0.703 & 0.01 \\
\hline Butyrate & 9.52 & 12.3 & 0.369 & $<0.01$ \\
\hline Valerate & 1.49 & 1.44 & 0.046 & 0.44 \\
\hline Isobutyrate & 1.07 & 1.05 & 0.063 & 0.86 \\
\hline Isovalerate & 2.22 & 1.44 & 0.121 & $<0.01$ \\
\hline $\mathrm{A}: \mathrm{P}$ & 3.39 & 2.75 & 0.136 & $<0.01$ \\
\hline
\end{tabular}

${ }^{\mathrm{z}} \mathrm{CCST}$, conventional corn silage-based TMR; BMRT, brown midrib corn silage-based TMR.

${ }^{\mathbf{y}}$ Individual VFA expressed as mol $100 \mathrm{~mol}^{-1}$. decreasing acetate proportion. Besides increasing concentration of total VFA, increasing propionate as a proportion of VFA may produce a signal to terminate meals. Propionate flux to the liver may increase greatly during meals (Benson et al. 2002) and propionate is rapidly metabolized in the liver (Reynolds 1995), which may down-regulate feed intake (Allen et al. 2009). Hence, the increased propionate proportion due to feeding BMRT may have interrupted a potential increase in DMI by steers fed BMRT through hypophagic response, resulting in no effect on DMI. Increased VFA concentration due to feeding the BMRT in this study suggests that enhanced ruminal fermentability by feeding BMR and can support increased energy supply for growth. In addition, an increase in propionate and a decrease in acetate corresponded to improvements in fiber digestion for corn silage (Eun and Beauchemin 2007). It is not uncommon to observe changes in VFA proportions as a direct effect of enhanced fiber digestion in the rumen, implying that feeding BMR may affect microbial growth or shift the metabolic pathways by which specific microbes utilize substrates, or both (Eun and Beauchemin 2007). Propionate is quantitatively the most important VFA precursor for glucose synthesis, and therefore has a major impact on hormonal release and tissue distribution of nutrients (Nagaraja et al. 1997). Consequently, increased VFA concentration and propionate proportion as a result of feeding BMR would contribute to improving nutrient supply and utilization, which may have resulted in the increases in ADG and G:F observed in the current study. Therefore, responses to feeding BMR may be greatest in situations where fiber digestion and fermentation are major contributors to net energy supply, which is often the case for growing beef steers. Additionally, it would be more beneficial to make a direct effect of feeding BMR on increased ruminal fermentability when it is fed at a relatively greater dietary concentration likely tested in the current study.

\section{Economic Analysis}

Feed cost based on BW gain was less $(P=0.03)$ for the BMRT than for the CCST (Table 4) due to similar DMI between the two treatments, but a tendency for increased ADG by feeding the BMRT. While total feed and non-feed costs were similar, total cost for BW gain was less $(P=0.01)$ for the BMRT compared with the CCST (1.72 vs. $1.93 \$ \mathrm{~kg}^{-1} \mathrm{BW}$ gain). Beginning and ending values of steers did not differ between treatments. Steers fed the BMRT tended to increase feed margin ( $\$ 415.7$ vs. $\$ 372.0, P=0.09$ ) and increased net return ( $\$ 195.2$ vs. 143.8 per steer, $P=0.03$ ) compared with those fed the CCST throughout the trial. These steers were fed during the same time to eliminate differences in cattle or feed prices due to market impacts. Observations by producers and agronomists indicate that yield of BMR is typically $10 \%$ less than CCS, so the cost of silage coupled with greater seed cost of brown-midrib corn is expensive to BMR relative to CCS. Therefore, the differences in net 
Table 4. Economic analysis of growing beef steers fed with different corn silage hybrids

\begin{tabular}{|c|c|c|c|c|}
\hline \multirow[b]{2}{*}{ Item } & \multicolumn{2}{|c|}{ Treatment $^{\mathbf{z}}$} & \multirow[b]{2}{*}{ SEM } & \multirow[b]{2}{*}{$P$} \\
\hline & CCST & BMRT & & \\
\hline Feed cost $\left(\$ \mathrm{~kg}^{-1} \mathrm{BW}\right.$ gain $)$ & 1.40 & 1.25 & 0.0448 & \\
\hline Total feed $\operatorname{cost}^{\mathrm{y}}(\$)$ & 165.8 & 160.2 & 5.03 & 0.4 \\
\hline Total non-feed $\operatorname{cost}^{\mathbf{x}}(\$)$ & 62.4 & 59.8 & 1.47 & 0.2 \\
\hline Total cost ${ }^{\mathrm{w}}$ ( $\$ \mathrm{~kg}^{-1} \mathrm{BW}$ gain $)$ & 1.93 & 1.72 & 0.056 & 0.0 \\
\hline Beginning value of steers ${ }^{v}(\$)$ & 1201 & 1167 & 31.1 & 0.4 \\
\hline Ending value of steers ${ }^{\mathbf{u}}(\$)$ & 1573 & 1582 & 37.8 & \\
\hline Feed $\operatorname{margin}^{t}(\$)$ & 372.0 & 415.7 & 17.48 & 0.09 \\
\hline Net return's $\left(\$\right.$ steer $\left.^{-1}\right)$ & 143.8 & 195.2 & 15.42 & 0.03 \\
\hline
\end{tabular}

${ }^{\mathrm{z}} \mathrm{CCST}$, conventional corn silage-based TMR; BMRT, brown midrib corn silage-based TMR.

${ }^{\mathbf{y}}$ Total feed cost $=$ total $\mathrm{kg}$ of individual feedstuff $\times$ individual feedstuff price, $\$ \mathrm{~kg}^{-1}$ throughout experiment.

${ }^{\mathrm{x}}$ Total non-feed $\operatorname{cost}=$ veterinary and medical costs + yardage + interest at $5 \%$.

${ }^{\text {w }}$ Total cost $=$ total feed cost + total non-feed cost.

\$209.0 per hundredweight (cwt).

"\$188.0 $\mathrm{cwt}^{-1}$.

${ }^{\mathrm{t}}$ Feed margin $=$ beginning value of steers - ending value of steers.

${ }^{\mathrm{s}}$ Net return $=$ feed margin $-($ total feed cost + total non-feed cost $)$.

return per steer are a direct result of differences in ADG. The difference of over $\$ 50$ per head is not only statistically significant, but is also economically important. Feeding BMRT compared with CCST increased returns by $36 \%$. If it is considered at even a relatively small feedlot, for instance feeding 1000 head of steers, total returns to the operation would increase by over $\$ 50000$ by feeding BMRT compared with CCST. A limitation to the analysis is that additional labor and technical service such as soil test for providing optimal conditions for BMR corn crop was not assumed. Likewise, potential weather impacts on BMR corn crop harvest yield were not considered on the economic analysis. Those minor components on the economic analysis will certainly discount sizable improvement of economic returns by feeding BMR silage to growing beef steers reported in the present study.

\section{CONCLUSIONS}

Forage quality affects feed intake, energy density and growth performance for growing beef steers. In addition, substantial increases in grain price or its fluctuation may cause some difficult conditions in feeding beef steers. Under these situations, forage quality will be of paramount importance for reducing purchased feed costs and improving economic returns on beef operation. The current study focused on a linkage between enhanced ruminal fermentability and improved growth and economic performance of growing beef steers fed BMR. Overall, the results reported in this study indicate that feeding BMR silage in typical growing beef steer diets may have beneficial effects for increasing ruminal fermentation with a favorable shift in fermentation pathways by producing more propionate and less acetate. These beneficial effects of feeding BMR silage may have contributed to tendencies to increases in ADG, G:F, feed margin, and net return compared with CCS. However, an increase in propionate may interfere with a potential benefit of feeding BMR to increase feed intake of growing beef steers.

\section{ACKNOWLEDGMENTS}

This project was funded by Mycogen Seeds (Indianapolis, IN) and Utah State University Extension Grants Program (Logan, UT). Additional support was provided by Utah Agricultural Experiment Station, Utah State University. We thank P. Galloway and other Utah State University Beef Research Unit staff for technical assistance. We also thank C. T. Noviandi and J. Vera (Utah State University, Logan, UT) for help with data collection and sample analysis.

Allen, M. S. 2000. Effects of diet on short-term regulation of feed intake by lactating dairy cattle. J. Dairy Sci. 83: 1598-1624. Allen, M. S. and Bradford, B. J. 2011. Control of energy intake through lactation. Pages 169-179 in Proc. Western Dairy Management Conf., Reno, NV.

Allen, M. S., Bradford, B. J. and Oba, M. 2009. Board-invited review: The hepatic oxidation theory of the control of feed intake and its application to ruminants. J. Anim. Sci. 87: 3317-3334.

Association of Official Analytical Chemists. 2000. Official methods of analysis. Vols. 1 and 2. 17th ed. AOAC, Gaithersburg, MD.

Benson, J. A., Reynolds, C. K., Aikman, P. C., Lupoli, B. and Beever, D. E. 2002. Effects of abomasal vegetable oil infusion on splanchnic nutrient metabolism in lactating dairy cows. J. Dairy Sci. 85: 1804-1814.

Bucholtz, D. L., Cantrell, R. P., Aztell, J. D. and Lechtenberg, V. L. 1980. Lignin biochemistry of normal and brown midrib mutant sorghum. J. Agric. Food Chem. 28: 1239-1241.

Calsamiglia, S., Cardozo, P. W., Ferret, A. and Bach, A. 2008. Changes in rumen microbial fermentation are due to a combined effect of type of diet and pH. J. Anim. Sci. 86: 702-711.

Campbell, C. P., Marshall, S. A., Mandell, I. B. and Wilton, J. W. 1992. Effects of source of dietary neutral detergent fiber on chewing behavior in beef cattle fed pelleted concentrates with or without supplemental roughage. J. Anim. Sci. 70: 894-903.

Chamberlain, C. C., Fribourg, H. A., Barth, K. M., Felts, J. H. and Anderson, J. M. 1971. Effect of maturity of corn silage at harvest on the performance of feeder heifers. J. Anim. Sci. 33: 161-166.

Cherney, J. H., Cherney, D. J. R., Akin, D. E. and Axtell, J. D. 1991. Potential of brown-midrib, low-lignin mutants for improving forage quality. Adv. Agron. 46: 157-198.

Eastridge, M. L. 1999. Brown midrib corn silage. Pages 179-190 in Proc. Tri-State Dairy Nutrition Conf., Fort Wayne, IN. The Ohio State University, Columbus, $\mathrm{OH}$.

Eun, J.-S. and Beauchemin, K. A. 2007. Enhancing in vitro degradation of alfalfa hay and corn silage using feed enzymes. J. Dairy Sci. 90: 2839-2851.

Fisher, D. S. 2002. A review of a few key factors regulating voluntary feed intake in ruminants. Crop Sci. 42: 1651-1655. Gehman, A. M., Kononoff, P. J., Mullins, C. R. and Janicek, B. N. 2008. Evaluation of nitrogen utilization and the effects of monensin in dairy cows fed brown midrib corn silage. J. Dairy Sci. 91: 288-300. 
Geishauser, T. 1993. An instrument for the collection and transfer of ruminal fluid and for the administration of water soluble drugs in adult cattle. Bovine Pract. 27: 38-42.

Gencoglu, H., Shaver, R. and Lauer, J. 2008. Brown midrib corn silage for lactating dairy cows: A contemporary review. http://www.uwex.edu/ces/dairynutrition/documents/BMRfeed ingtrialreview2008web.pdf [2014 Aug. 20].

González, L. A., Manteca, X., Calsamiglia, S., SchwartzkopfGenswein, K. S. and Ferret, A. 2012. Ruminal acidosis in feedlot cattle: Interplay between feed ingredients, rumen function and feeding behavior (a review). Anim. Feed Sci. Technol. 172: 66-79.

Holt, M. S., Eun, J.-S., Thacker, C. R., Young, A. J., Dai, X. and Nestor Jr., K. E. 2013a. Effects of feeding brown midrib corn silage with high dietary concentration of alfalfa hay on lactational performance of Holstein dairy cows for the first 180 days of lactation. J. Dairy Sci. 96: 515-523.

Holt, M. S., Neal, K., Eun, J.-S., Young, A. J., Hall, J. O. and Nestor Jr., K. E. 2013b. Corn silage hybrids and quality of alfalfa hay affect dietary nitrogen utilization by early lactating dairy cows. J. Dairy Sci. 96: 6564-6576.

Holt, M. S., Williams, C. M., Dschaak, C. M., Eun, J.-S. and Young, A. J. 2010. Effects of corn silage hybrids and dietary nonforage fiber sources on feed intake, digestibility, ruminal fermentation, and productive performance of lactating Holstein dairy cows. J. Dairy Sci. 93: 5397-5407.

Isaac, R. A. and Johnson, W. L. 1985. Elementary analysis of plant tissue by plasma emission spectroscopy: collaborative study. J. Assoc. Off. Anal. Chem. 68: 499-505.

Keith, E. A., Colenbrander, V. F., Perry, T. W. and Bauman, L. F. 1981. Performance of feedlot cattle fed brown midrib-three or normal corn silage with various levels of additional corn grain. J. Anim. Sci. 52: 8-13.

Krehbiel, C. R., Cranston, J. J. and McCurdy, M. P. 2006. An upper limit for caloric density of finishing diets. J. Anim. Sci. 84 (E. Suppl.): E34-E49.

Mertens, D. R. 1987. Predicting intake and digestibility using mathematical models of ruminal function. J. Anim. Sci. 64: $1548-1558$.

Nagaraja, T. G., Newbold, C. J., Van Nevel C. J. and Demeyer, D. I. 1997. Manipulation of ruminal fermentation. Pages 523-632 in The rumen microbial ecosystem. 2nd ed. P. N. Hobson and C. S. Stewart, eds. Blackie Academic and Professional, New York, NY.

National Research Council. 1996. Nutrient requirements of beef cattle. 7th rev. ed. National Academy Press, Washington, DC.
Oba, M. and Allen, M. S. 1999. Effects of brown midrib 3 mutation in corn silage on dry matter intake and productivity of high yielding dairy cows. J. Dairy Sci. 82: 135-142.

Oba, M. and Allen, M. S. 2000. Effects of brown midrib 3 mutation in corn silage on productivity of dairy cows fed two concentrations of dietary neutral detergent fiber: 1. Feeding behavior and nutrient utilization. J. Dairy Sci. 83: 1333-1341. Owens, F. N., Secrist, D. S. and Gill, D. R. 1997. The effect of grain source and grain processing on performance of feedlot cattle: A review. J. Anim. Sci. 75: 868-879.

Reynolds, C. K. 1995. Quantitative aspects of liver metabolism in ruminants. Pages 351-372 in W. V. Englehardt, S. LeonhardMarek, G. Breves, and D. Geisecke, eds. Ruminant physiology: Digestion, metabolism, growth and reproduction. Ferdinand Enke Verlag, Stuttgart, Germany.

Rode, L. M., Yang, W. Z. and Beauchemin, K. A. 1999. Fibrolytic enzyme supplementations for dairy cows in early lactation. J. Dairy Sci. 82: 2121-2126.

SAS Institute, Inc. 2011. SAS/STAT user's guide. Release 9.3. SAS Institute Inc., Cary, NC.

Sattler, S. E., Funnell-Harris, D. L. and Pedersen, J. F. 2010. A review: Brown midrib mutations and their importance to the utilization of maize, sorghum, and pearl millet lignocellulosic tissues. Plant Sci. J. 178: 229-238.

Taylor, C. C. and Allen, M. S. 2005. Corn grain endosperm type and brown midrib 3 corn silage: Ruminal fermentation and $\mathrm{N}$ partitioning in lactating cows. J. Dairy Sci. 88: 1434 1442 .

Tjardes, K. E., Buskirk, D. D., Allen, M. S., Ames, N. K., Bourquin, L. D. and Rust, S. R. 2000. Brown midrib-3 corn silage improves digestion but not performance of growing beef steers. J. Anim. Sci. 78: 2957-2965.

USDA-Agricultural Marketing Service. 2014. http://www.ams. usda.gov/AMSv1.0/lsmnpubs [2014 Aug. 27].

Utah Agricultural Statistics Service. 2014. http://www.nass. usda.gov/Statistics_by_State/Utah/index.asp. [2014 Aug. 27].

Vogel, K. P. and Jung, H. J. G. 2001. Genetic modification of herbaceous plants for feed and fuel. Crit. Rev. Plant Sci. 20: 15-49.

Weiss, W. P. and Wyatt, D. J. 2006. Effect of corn silage hybrid and metabolizable protein supply on nitrogen metabolism of lactating dairy cows. J. Dairy Sci. 89: 1644-1653.

Weller, R. F. and Phipps, R. H. 1986. The feeding value of normal and brown midrib-3 maize silage. J. Agric. Sci. (Camb.) 106: $31-35$. 